\title{
Dinar dan Dirham Sebagai Alternatif Mata Uang: Sebuah Tinjauan Literatur
}

\author{
Ririn Noviyanti \\ Program Studi Hukum Ekonomi Syariah, Fakultas Syariah, \\ Institut Agama Islam (IAI) Al-Qolam \\ E-mail: rinoyanti@gmail.com
}

\begin{abstract}
The issue of justice becomes a serious problem because of the lack of attention to the current system of justice. In the end, many of the economic actors are realizing that the current system is not capable of delivering optimal results. Various attempts were made to optimize the results but the results were in vain. Various policies have been made to provide solutions to the existing problems, but still unable to prevent the various economic crises that occur in the current system. This study aims to conduct in-depth discussion of the dinar and dirham as an alternative to the world currency solutions using literature approach. Based on the exposure, it can be concluded that dinar and dirham can and can be a solution of the international monetary system and replace the current monetary system. It is therefore ideal for all Muslim countries to embark on the implementation of the Islamic monetary system using dinar and dirham.
\end{abstract}

Keywords: dinars and dirhams, currencies, Islamic Economics.

\section{Pendahuluan}

Di dalam kegiatan perekonomian setidaknya terdapat bermacam-macam tujuan yang ingin di capai. Adapun tujuan tersebut meliputi, pembangunan negara, pertumbuhan ekonomi, pemerataan pembagian pendapatan dan stabilisasi ekonomi, dan yang terakhir adalah adanya keadilan dalam kegiatan perekonomian tersebut. Akan tetapi dewasa ini, masalah keadilan menjadi suatu masalah yang serius karena kurangnya perhatian sistem yang ada saat ini terhadap masalah keadilan tersebut. Pada akhirnya, banyak pihak dari pelaku ekonomi yang menyadari bahwa sistem yang ada saat ini tidaklah mampu memberikan hasil yang optimal. Berbagai upaya dilakukan untuk mengoptimalkan hasil akan tetapi hasilnya sia-sia. Berbagai kebijakan telah dilakukan untuk memberikan solusi terhadap permasalahan yang ada, akan tetapi tetap tidak mampu mencegah 
berbagai krisis ekonomi yang terjadi dalam perjalanan sisitem yang berlaku pada saat ini. Bahkan krisis tersebut semakin semakin sering terjadi, dan yang terakhir yaitu krisis yang terjadi di Amerika Serikat beberapa waktu yang lalu. Dan semua ini tidak lain disebabkan karena ketidakadilan dalam perekonomian.

Selain itu, dampak daripada ketidakadilan adalah pincangnya distribusi pendapatan antar negara. Dan kecenderungannya adalah, yang kaya semakin kaya, dan yang miskin tentu akan menjadi semakin miskin. Sedangkan usaha untuk mengatasi problem tersebut lagi- lagi belum menunjukkan hasil yang memuaskan. Dan akhirnya, semakin lebarlah jurang pemisah antara kedua negara tersebut. Lantas, dari manakah sebenarnya ketidakadilan itu bermula ?, seringkali negara berkembang menjadi kambing hitam dengan dalih ketidak seriusannya dalam melakukan kegiatan perekonomian, yaitu; produktivitasnya yang rendah, hingga praktek manajemennya yang tidak efektif dan efisien dan rusuh dengan merajalelanya korupsi, kolusi dan nepotisme yang terjadi. Dengan kondisi tersebut, maka mereka tidak akan bisa mamaksimalkan alokasi dana dan sumber daya yang ada untuk pembangunan. Boleh dikatakan, meskipun negara berkembang tersebut dalam sehari mereka bekerja penuh 24 jam penuh, belum tentu mereka bisa mengejar ketertinggalan, dikarenakan desain sistem moneter yang menggunakan fiat money sebagai alat untuk mendapat keuntungan bagi negara yang berkuasa dan memainkan peranan ekonomi di dunia. Berbicara mengenai keadilan, sistem moneter Islami merupakan bagian dari sistem ekonomi Islami dimana dinar memiliki peran yang signifikan dalam mewujudkan keadilan ekonomi. Di dalam kerangka menghasilkan sistem moneter yang adil, maka sistem ekonomi yang ada haruslah memenuhi beberapa persyaratan tertentu. Dan salah satu persyaratannya adalah penggunaan mata uang emas di dalam segala transaksi ekonomi termasuk dalam transaksi perdagangan internasional. Karena tanpa penggunaan sistem dinar, keadilan yang akan dicapai akan kurang sempurna.

\section{Sejarah Mata Uang: Barter, Dinar dan Dirham}

Kemunculan uang saat pertama kali di dunia belum ada konsensus dari para ekonom untuk memperkirakan bagaimana uang tersebut dipergunakan. Pada masyarakat primitif istilah uang memang belum ditemukan, namun sebagai embrio akan kebutuhan yang mendesak manusiapun lambat laun menerapkan sistem barter yang perkembangannya nanti mencuat istilah uang sebagai ganti dari sistem barter. Perkembangan uang ini selanjutnya menjadi alat tukar sampai kini. Hal ini terjadi sebab pertukaran secara barter mengalami banyak kendala dibandingkan dengan uang. Kegiatan ini dapat dicermati bahwa pertukaran secara barter dapat berlangsung apabila penilaian terhadap barang yang akan dipertukarkan oleh masing-masing pemiliknya sudah sesuai baik jenis barang maupun nilai yang diinginkan. Jika salah seorang tidak menghendaki dan tidak 
membutuhkan terhadap barang yang akan ditukar, maka proses barter tidak dapat terjadi. Sebelum pemikiran penggunaan uang yang dipakai secara umum oleh masyarakat, orang telah banyak mempergunakan benda jenis logam ${ }^{1}$ sebagai alat tukar. Lagi-lagi sebab berat dan merasa kesulitan untuk membawa alat tukar yang terbuat dari logam, orang mulai memikirkan pembuatan alat tukar dari logam yang lebih praktis. Inilah cikal bakal adanya uang logam. Demikian halnya dengan cikal bakal uang kertas, pada zaman dahulu para pedagang yang menyimpan emas (dinar) di bank menerima surat tanda penitipan emas dari bank. Lambat laun surat bukti penitipan emas tersebut digunakan sebagai alat pembayaran.

Dalam lintas sejarah Islam, perdagangan merupakan dasar perekonomian di jazirah Arab sebelum Islam datang. Adapun mata uang yang dipergunakan pada waktu itu adalah dinar dari Roma $^{2}$ dan dirham dari persia. ${ }^{3}$ Hal ini dapat dimaklumi karena bangsa romawi dan persia merupakan mitra dagang bangsa Arab. Di samping, letak geografis daerah Arab terutama Hijaz. Sehingga memberi keuntungan tersendiri bagi daerah tersebut untuk dilalui oleh rute perdagangan antara Persia dan Roma, Roma ke India serta daerah jajahannya seperti Syam (Syiria), Etiopia dan Yaman. ${ }^{4}$ Adapun nilai satu dinar pada waktu itu sama dengan sepuluh dirham. ${ }^{5}$ Setelah Islam datang, mata uang dinar dan dirhampun masih digunakan sebagai alat transaksi pada zaman Nabi. Bahkan pada zaman ini telah ditetapkan bahwa mata uang dinar dan dirham merupakan sebagai alat pembayaran yang sah. Menurut Kadim as-Sadr dalam tulisannya "Money and Monetary Policise in Early Islamic Period" yang kemudian dikumpulkan oleh Baqir dan Hasan dalam buku Essay. Menjelaskan, bahwa koin dinar dan dirham ternyata memiliki kandungan emas dan perak yang tetap (fix) sehingga stabilitas nilai tukarnya stabil. Hal ini terjadi bukan hanya pada masa Rasul melainkan jauh sampai pada masa Dinasti Umayyah. Akan tetapi pada masa Umayyah juga dan Abbasiyah berat dinar dan dirham berubah demikian pula di persia. ${ }^{6}$ Pada masa berikutnya kandungan dinar (emas) dan dirham (perak) mengalami perubahan di wilayah-wilayah kekuasaan Islam lainnya. Sehingga bisa disimpulkan dinar dan dirham meski pada awalnya dari Romawi dan Persia, Islamlah kemudian yang menorehkan pemberlakuan kedua mata uang tersebut dalam kurun waktu yang

\footnotetext{
${ }^{1}$ Hanya logam yang tidak berkarat yang dapat digunakan sebagai alat tukar seperti perak yang dikenal sebagai mata uang dirham dan emas yang dikenal mata uang dinar.

${ }^{2}$ Uang emas dan perak diperkenalkan oleh Julius Caesar dari romawi pada tahun 46 SM. Julius Caesar pulalah yang memperkenalkan standar konversi dari uang emas ke uang perak dan sebaliknya dengan perbandingan 12:1 untuk perak terhadap emas dan standar ini berlaku di belahan dunia eropa selama sekitar 1250 tahun yaitu sampai tahun 1204. Lihat; Muhaimin Iqbal, Dinar the real money, (Jakarta; Gema Insani Press, 2009), 29

${ }^{3}$ Ali Akbar Fayyad, History of Islam, (Tehran: Enteshart Daneshgah Tehran, 1958), 11-12

${ }^{4}$ Ibid, Ali Akbar Fayyad, 11-12

5 Abdul Hay al-Kattani, The Sistem Of Propethic Development Goverment Calld The Administrative Procedure, Vol. II , (Beirut: Dar Ihya At-thuras al 'Arabi, t.t.), 412-428.

6 Baghir al Hasani \& Abbas Mirakhor, Essay on Iqtisâd Islamic Approach to Economic Problems, (USA: Nur, 1989), 199-201
} 
sangat lama berabad-abad hingga Dinasti Utsmani pada tahun 1924. Standarisasi uang dinar dan dirham pada masa itu berpijak kepada hadist rasulullah saw, "Timbangan adalah timbangan penduduk Makkah, dan takaran adalah takaran penduduk Madinah” (HR . Abu Daud). Pada zaman khalifah Umar bin Khattab yaitu pada tahun $642 \mathrm{M}$, bersamaan dengan pencetakan uang dirham pertama kali di kekhalifahan, standar hubungan berat antara uang emas dan perak dibakukan menjadi berat 7 dinar sama dengan berat 10 dirham. Sedangkan berat 1 dinar sama dengan atau sama dengan berat 72 butir gandum ukuran sedang yang dipotong kedua ujungnya. ${ }^{7}$ Untuk melihat peninggalan sejarah mata uang Islam dapat dilihat ada empat koleksi peninggalan mata uang salah satu diantaranya adalah mata uang yang dicetak pada masa Khalifah Ali Ra., sedangkan tiga lainnya adalah mata uang perak yang dicetak di Damaskus dan Mervi sekitar tahun 60-70 H. ${ }^{8}$ Sebenarnya, di zaman khalifah Umar dan Utsman Ra. mata uang juga telah dicetak mengikuti gaya dirham Persia dengan perubahan pada tulisan yang tercantum pada mata uang tersebut meskipun, diawal pemerintahan Umar Ra. pernah timbul pemikiran untuk mencetak uang dari kulit. Ide tersebut dibatalkan karena tidak disetujui para sahabat yang lain.

Mata uang khilafah Islam mempunyai ciri khusus yang dicetak pada masa Khalifah Ali ra. Namun sayang, peredarannya sangat terbatas karena kondisi politik pada saat itu. Mata uang dengan gaya persia juga 'lagi-lagi' di cetak pada zaman Mua`wiyyah dengan mencantumkan gambar dan pedang, Gubernur Irak, pada masa pemerintahan zaid, mencetak uang dengan mencantumkan nama khalifah. Al-hasil, modus yang dilakukan oleh Mu'awiyyah dan Ziad berupa pencantuman gambar dan nama kepala pemerintahan pada mata uang. Peninggalan tersebut kiranya masih dipertahankan sampai saat ini termasuk di indonesia dalam pembuatan uang dengan pencantuman gambar dan kepala pemerintahan. Meskipun mata uang yang beredar pada saat itu belum berbentuk bulat sepertui uang logam pada saat sekarang, baru pada masa ibn Zubair mata uang dengan bentuk bulat dicetak namun peredaranya hanya sebatas wilayah Hijaz.Terobosan unik yaitu seperti gubernur kufah yang mencetak uang dengan gaya kombinasi Persia dan Romawi. Pada tahun 72-74 H --Bishri bin Marwan-mencetak mata uang yang disebut atawiyya. Sampai pada zaman ini mata uang khalifah beredar bersama dinar Romawi dan dirham Persia serta sedikit himyarite Yaman. Barulah pada zaman Abdul Malik $(76 \mathrm{H})$ tempat percetakan dapat terorganisasi dengan kontrol pemerintah yaitu dengan didirikannya tempat percetakan di Dar A’jarb, Suq Ahwaz, Sus, Jay, Manadar. Maysan, Ray, dan Abarqubadh. ${ }^{9}$

\footnotetext{
${ }^{7}$ Op.Cid, Muhaimin Iqbal. 30

8 Adirwarman A Karim, Ekonomi Islam; Suatu Kajian Kontemporer, (Jakarta; Gema Insani Press, 2002), 58.

${ }^{9}$ Ibid, Adirwarman A Karim,.. 60
} 
Dirham dan dinar memiliki nilai yang tetap karena itu tidak ada masalah dalam pertukaran uang, jika dinar dijadikan sebagai satuan nilai maka nilai dirham adalah perkalian dari dirham; dan jika diasumsikan dinar sebagai unit moneter nilainya adalah sepuluh kali dirham. Walau pun demikian, dirham lebih umum digunakan daripada dinar sebab aspek politis yaitu hampir seluruh wilayah kekaisaran persia yang mata uangnya dirham dapat dikuasai oleh angkatan perang Islam. Sementara tidak semua wilayah kekaisaran Romawi yang memiliki mata uang dinar dapat dikuasai Islam karena itu menjadi wajar kiranya bahwa mata uang dirham lebih umum di dunia perdagangan bangsa Arab saat itu. ${ }^{10}$ Sehingga dinar dan dirham menjadi mata uang dunia yang tidak dibatasi tempat dan waktu sampai masa keemasan Islam. Dengan kata lain mata uang dinar dan dirham fix. Untuk itulah banyak pemikiran dari tokoh-tokoh muslim di dunia baik melalui Islamic Development Bank (IDB) -yang didirikan 23 April 1975-- maupun cendikiawan muslim Indonesia melalui Bank Muamalat Indonesia (BMI) sebut saja Cecep Maskanul Hakim dan lain-lainnya mencoba menggulirkan dan mencanangkan mungkinkah dinar emas akan kembali dijadikan sebagai mata uang dunia?. ${ }^{11}$

Dinar adalah mata uang dengan nilai fisik dan nilai intrinsik yang sama, karena berdasarkan emas. Di Indonesia, dinar memang belum populer. Dinar diproduksi dan diedarkan di Indonesia sejak tahun 2001. Penggunaan koin emas dinar oleh masyarakat Indonesia masih sangat terbatas, baik dari segi fungsi maupun kuantitas penggunaan. ${ }^{12}$ Berdasarkan standard World Isllamic Trade Organization (WITO), nilainya setara dengan 4,25 gr emas 22 karat, dengan diameter $23 \mathrm{~mm}$. Bentuk dinar di seluruh dunia berbeda-beda.l Di Indonesiapun, bentuknya berbeda-beda, tergantung institusi yang mengeluarkannya. Dinar yang dikeluarkan oleh Baitulmaal Muamalat (B-Dinar) sisi mukanya bergambar Masjidil Aqsha, tulisan Baitulmaal, cahaya di atas Masjidil Aqsha, da gerigi roda.Sementara sisi bagian dalam tertulis dua kalimat syahadat. Bentuk memang tidaklah terlalu signifikan, pada dasarnya semua lembaga jelas berhak mengeluarkan dinar asal memenuhi standar WITO kriterianya yakni harus 4,25 gr, 2 karat, berdiameter $23 \mathrm{~mm}$. Apalagi seandainya bila pemerintah memiliki political will menjadikan dinar sebagai mata uang, bentuknya harus sama digunakan di seluruh Indonesia setelah melalui WITO sebagai lembaga akeditasinya. Berlakunya suatu mata uang perkembangan selanjutnya (pasca dinar dan dirham) dapat dicermati dibatasi oleh tempat dan waktu tidak berlaku sepanjang masa, misalnya Rupiah hanya diterima di wilayah Indonesia, Rupe

\footnotetext{
${ }^{10}$ Op.Cid, Baghir al Hasani \& Abbas Mirakhor,.. 201-202

${ }^{11}$ Karnaen Perwataatmadja \& Muhammad Syafi'i Antonio, Apa Dan Bagaimana Bank Islam, (Jogjakarta: Dana Bakti Wakaf, 1992), 58. Bandingkan Adiwarman A Karim, Ekonomi Islam; Suatu Kajian Kontemporer, 146-148

${ }^{12}$ Alia, "Dinar Aman, Menguntungkan, Bebas Riba”, (Jakarta: Alia, 2004), 61
} 
hanya diterima di wilayah India --dan banyak lagi mata uang negara lainnya-sebagai alat pembayaran yang sah, dan tidak berlaku di wilayah lain.

\section{Akhir Bretton Woods Agreement dan Problem Uang Kertas (Fiat Money)}

Berakhirnya sistem standar emas klasik atau lebih dikenal dengan "Classical gold standard" yang terus diikuti dengan diakhirinya sistem pengganti yang mirip dengannya, yaitu sistem bretton woods pada awal tahun 1971, manandai era baru sistem moneter internasional dibawah sisitem kurs mengmbang (flaxible exchang rate). Namun, dalam kenyatannya sistem ini didominasi oleh dolar, maka duncan dalam bukunya The Dollars Crisis, lebih suka menyebutnya sebagai dollar standar. Julukan tersebut dikarenakan dolar dijadikan cadangan mata uang utama (the core reserve currency) duni internasional menggantikan emas, yang menjadi cadangan utama dunia ketika sistem bretton woods atau sistem gold standard klasik diberlakukan. ${ }^{13}$ Lebih lanjut, Duncan berpendapat, bahwa salah satu ciri keunggulan sistem gold standard adalah terdapatnya mekanisme penyesuain otomatis (automatic adjusment) yang tidak dimiliki oleh sistem yang lain seperti dollar standard. ${ }^{14}$

Pembubaran sistem bretton woods oleh Amerika. Dilatarbelakangi terjadinya peperangan anatar Amerika dengan Vietnam, akibatnya Amerika mencetak dollar guna meningkatkan belanja fiskalnya diantaranya untuk membiayai perang tersebut. Dengan demikian, maka akan berdampak kepada defisit anggaran yang makin membesar sementara rasio antara supply dollar dan cadangan emasnya terus merosot. Pada periode tersebut stok emas Amerika merosot dari 20 milar dollar menjadi hanya 9 miliar Dollar dan Amerika kemudian mengalami defisit cadangan emas. ${ }^{15}$ Taqiyuddin an-Nabhani berpendapat bahwa secara politis langkah yang dilakukan oleh Amerika untuk menghentikan pengkaitan Dollar dengan emas adalah didorong oleh keinginan Amerika untuk memposisikan dollar sebagai standar moneter internasional hingga menguasai pasar moneter internasional. Oleh karena itu standar emas kemudian dianggap tidak lagi dapat dipergunakan di dunia. Standar moneter Bretton Woods kemudian hancur dan kurs pertukaran mata uang terus berfluktuasi. Dari sinilah muncul berbagai kesukaran dalam mobilitas barang, uang dan orang. ${ }^{16}$ Sejak saat itu mata uang dunia menjadi tidak stabil. Mata uang AS dan seluruh dunia terus bergolak. Fluktuasi tingkat nilai tukar menjadi sulit untuk diprediksi bahkan kadangkala bergerak secara ekstrim. Belum lagi inflasi terus membumbung akibat percetakan

\footnotetext{
13 M. Luthfi hamidi, Gold Dinar; Sistem Moneter yang Stabil dan Berkeadilan, (Jakarta; Senayan abadi publishing, 2007), 136

${ }^{14}$ Ibid, M. Luthfi hamidi, 137

15 <www.the-privateer.com/1933-gold-confiscation.html>

16 Taqiyuddin An-Nabhany, An Nidzamu al-Iqtishady fi Islam, (Jakarta; Dârul Ummah, 1999), 271
} 
mata uang kian tak terkendali. Suatu keadaan yang sangat meresahkan para pelaku ekonomi. Inilah diantara konsekuensi yang ditimbulkan oleh mata uang fiat.

Secara sederhana kemunculan uang kertas mulanya adalah sebagai representasi dari komoditas khsususnya emas. Hal ini dilakukan akibat sulitnya untuk melakukan transaksi dengan membawa emas khususnya pada barang-barang yang bernilai tinggi. Orang akan menerima uang representasi tersebut sebab ada jaminan dari pihak yang mengeluarkan kertas tersebut dalam hal ini pemerintah bahwa kertas tersebut dapat ditukar emas senilai dengan yang dinyatakan dalam kertas tersebut. Pemegangnya dapat menukar uang tersebut kapanpun dan berapapun ia mau. Namun perlahan-lahan negara justru mengeluarkan kertas jauh lebih banyak dari emas yang mereka miliki. Akibatnya kertas-kertas tersebut tak lagi cukup untuk dikonversi dengan emas. Akhirnya masyarakat dipaksa untuk menggunakan kertas tersebut sebagai alat transaksi. Dalam sejarah moneter dunia dijumpai bahwa penggunaan mata uang kertas yang tidak ditopang (backed) oleh komoditas seperti emas menyebabkan sejumlah masalah yang sangat serius dalam perekonomian. Diantara masalah tersebut adalah:

1) mata uang kertas menyebabkan inflasi yang tinggi. Akibatnya nilai uang terus merosot. Sebagai contoh, pada awal abad ke-9, Cina mengedarkan uang kertas sekaligus sebagai negara pertama yang menggunakan uang kertas untuk mengganti tembaga yang saat itu mengalami kelangkaan. Cina telah memproduksi mata uang kertas yang sama sekali tidak ditopang oleh emas atau komoditas lainnya. Namun alih-alih membenahi perekonomiannya, pada tahun 1051 justru Cina terjerembab pada tingkat inflasi yang sangat tinggi akibat produksi uang kertas yang terus berlangsung.

2) legitimasi mata uang kertas sangat rapuh sebab ia sama sekali tidak disandarkan pada komoditas yang bernilai seperti emas dan perak. Ia hanya ditopang oleh undang-undang yang dibuat pemerintahan suatu negara. Jika keadaan politik dan ekonomi negara tersebut tidak stabil maka tingkat kepercayaan terhadap mata uangnya juga akan menurun. Para pemilik uang akan beramai-ramai beralih ke mata uang lain atau komoditas yang dianggap bernilai sehingga nilai uang tersebut terpuruk.

3) uang kertas telah menjadi sumber pemasukan peerintah yang paling mudah. Dengan biaya produksi yang sangat rendah dibanding nilai nominal yang dikandungnya, mereka dengan mudah mencetak uang-uang kertas (di sejumlah negara dilakukan oleh Bank sentral). Uang tersebut kemudian 'dipaksakan' kepada rakyat untuk diterima sebagai alat tukar. Dengan menukarkan menukarkan uang tersebut dengan barang dan jasa yang diproduksi oleh rakyatnya, pemerintah dapat menikmati hasil keringat rakyatnya dengan mudah. Dengan kata lain mata uang kertas telah menjadi alat pemerasan negara terhadap rakyatnya. Rakyat kemudian menjadi korban dengan inflasi yang tinggi. 
4) penggunaan mata uang kertas menciptakan ketidakadilan dalam kegiatan ekonomi. Sebagai contoh biaya untuk memproduksi uang kertas 100 dollar adalah 20 sen maka seignorage-nya sebesar 99.80 dollar. Dengan kata lain setiap kali AS mencetak satu lembar uang 100 dollar, maka ia akan mendapatkan keuntungan 99,80 dollar. Federal Reserve, bank sentral AS telah menikmati seignorage yang sangat besar dengan mengeluarkan dollar sejak mata uang tersebut menjadi cadangan mata uang internasional yang paling dominan. Dollar memiliki daya beli yang kuat di luar AS sehingga dengan leluasa AS memanfaatkan kesempatan ini untuk terus mencetak Dollar. ${ }^{17}$

5) mata uang kertas telah mendorong gelembung ekonomi yang dapat berujung pada ledakan ekonomi. Bahaya kerapuhan dollar sebagai mata uang kertas paling kuat saat ini juga telah diwanti-wanti oleh Samuelson sebagaimana yang ditulis dalam The Washington Post (17/11/004). Menurutnya pada tahun 2004 saja, investor swasta telah memborong saham dan obligasi AS. Secara keseluruhan investor asing telah memegang 13 persen dari total saham AS, 24 persen obligasi korporasi dan 43 persen surat-surat berharga pemerintah AS (treassury securities). Sturuktur kepemilikan aset tersebut sangat berbahaya. Alasannya, saat ini dunia telah menerima dollar lebih banyak daripada yang dia inginkan. Jika terdapat momentum krusial sewaktu-waktu saham-saham dan obligasi tersebut akan dilepas oleh pemiliknya dan resesi global yang akut akan terjadi. Orang-orang beramai ramai menjual dollar dan beralih ke mata uang kuat lainnya seperti Euro dan Yen dan nilai dollar dipastikan turun signifikan. Anjloknya dollar berarti nilai dari saham dan obiligasi yang dipegang oleh investor asing tersebut juga akan terjun bebas. Mereka berlomba menjual aset-aset yang mereka memiliki. Pada saat itulah pasar-pasar saham akan anjlok secara tajam dan dollar AS akan kehilangan nilainya. ${ }^{18}$ Bahaya ini kian mengancam tatkala dunia telah dibanjiri dolar. Di pasar-pasar uang saja, terdapat gelembung-gelembung dollar AS yang berjumlah 80 triliun Dollar AS pertahun. Jumlah ini 20 kali lipat melebihi nilai perdagangan dunia, yang jumlahnya sekitar 4 triliun Dollar AS pertahun. Artinya, gelembung itu bisa membeli segala yang diperdagangkan sebanyak 20 kali lipat dari biasanya. Gelembung semakin lama semakin membesar dan secara pasti gelembung itu suatu saat akan meledak yang menyebabkan keruntuhan ekonomi global yang jauh lebih buruk dari depresi ekonomi tahun 1929. ${ }^{19}$

\footnotetext{
${ }^{17}$ Op.Cid, Ahamed Kameel Mydin Meera. 37

18 http://www.washingtonpost.com Robert J. Samuelson, Is the Global Economy Unstable? /wp- dyn/articles/A38568-2005Mar15.html

${ }^{19}$ Umar Ibrahim Vadilo, The Return of the Gold Dinar, (Cape Town; Madinah Press, 1996), 52
} 


\section{Relevansi Mata Uang Dinar dan Dirham beserta Keunggulannya}

Sejumlah kalangan mempertanyakan relevansi mata uang emas dalam praktiknya sebagai mata uang, mulai dari tataran teknis, ekonomis, politis hingga yang bertaraf ideologis. Salah satu keraguan yang cukup dominan adalah apakah persediaan emas cukup jika dikonversikan dengan jumlah uang yang beredar seperti di Indonesia atau bahkan di dunia?. Saat ini diperkirakan jumlah emas dipermukaan bumi yang telah diproduksi mencapai 5 miliar ons. Di sisi lain jumlah uang yang beredar baik berupa uang kartal (uang kertas dan koin) ditambah dengan uang giral (bank deposits) atau dikenal dengan M1 nilainya sekitar 30 triliun dolar. Jika harga emas saat ini USD 6,000/ons, maka nilai supply emas tersebut cukup untuk menggantikan peran uang kertas. Untuk membeli barang seharga 1 dolar misalnya cukup dengan 0,0002 oz emas. Belum lagi ketika perak juga dijadikan sebagai mata uang resmi yang di dalam Islam dikenal dengan istilah dirham, ketersedian uang untuk kegiatan ekonomi akan sangat memadai. Untuk menutupi kebutuhan transaksi yang nilainya lebih kecil, cukup diatasi dengan pencetakan dirham dalam berbagai ukuran. Larangan menimbun emas dan perak (kanz atau hoarding) sebagaimana yang telah ditetapkan oleh Islam menjadi sangat relevan agar perputaran emas dan perak sebagai uang terus berjalan.

Negara berkembang sudah saatnya berbenah dan lebih giat lagi memperjuangkan kebangkitan ekonomi. Hanya dengan kebangkitan ini, mereka bisa berdaya, memerangi kebodohan, kemiskinan dan rendahnya kualitas hidup. Kebangkitan ekonomi bisa dimulai dengan meningkatnya kerjasama dalam perdagangan internasionalnya. ${ }^{20}$ Meningkatkan perdagangan yang sudah lama stagnan, tentu perlu cara-cara yang tidak konvensional. Langkah-langkah terobosan sangat dinantikan untuk memecah kebekuan. Proposal penggunaan gold dinar dirham dalam perdagangan internasional adalah salah satunta. Proposal ini tidak terkait dengan agama atau ideologi, akan tetapi prposal ini berangkat dari kesadaran perlunya mengoreksi sistem moneter internasional yang tidak adil dan hanya menguntungkan bagi segelintir mereka yang menguasainya. Dan neara berkembang adalah korban daripada ketidakadilan moneter yang saat ini bekerja. ${ }^{21}$ Proposal gold dinar bila terlaksana bisa menjadi bentuk reformasi moneter yang akan mempengaruhi lanskap baru moneter dunia. Khususnya bagi negara - negara yang terhimpun dalam OKI, reformasi moneter melalui gold dinar dalam jangka pendek lebih realistis dari pada keingainan dari pada keinginan untuk membentuk pasar bersama (Islamic common market) yang membutuhkan energi dan waktu yang lama untuk mewujudkannya. Disebut realistis karena, pertama, dari sisi jumlah pendukungnya gold dinar bisa dilakukan oleh hanya dua negara. Dengan demikian, tidak perlu mem-push semua anggota OKI yang secara ekonomi memang belum siap untuk turut serta, akan tetapi hanya negara - negara

\footnotetext{
${ }^{20}$ Ibid, M. Luthfi hamidi, 179

${ }^{21}$ Ibid, h. 180
} 
yang telah siap saja sehingga akan berimplikasi pada hematnya waktu dan energi yang digunakan untuk mendesainnya. Kedua, tidak seperti pasar bersama, pelaksanaan gold dinar tidak mensyaratkan negara yang terlibat harus memangkas tarif pajak, dan restriksi perdagangan yang menjadi sumber pendapatannya. Namun, bukan berarti perdagangan menjadi terhambat karena gold dinar secara build in memberikan insentif yang lebih murah, absennya biaya transaksi yang lebih murah, absenya biaya hedging, dan berbagai peningkatan kerja sama ekonomi yang lebih intensif. Dan, ketiga, karena bisa dimulai oleh paling tidak dua negara, maka mereka bisa dievaluasi dan menjadi contoh bagi negara lainnya. Bila memang dalam perjalanannya mendatangkan manfaat, semestinya negara negara lain akan bergabung dengan sendirinya. Akan tetapi apabila manfaatnya dirasa kurang optimal, maka kedua negara tersebut bisa melakukan berbagai kajian untuk memperbaikinya. $^{22}$

Sepanjang sejarah manusia aneka alat tukar telah digunakan, mulai dari yang paling sederhana seperti bahan makanan, kulit binatang, tembakau, logam kertas hingga manusia. Dari sekian banyak bentuk uang tersebut, emaslah yang paling banyak diminati. Hal ini karena dari sisi fisik emas memiliki keunggulan dari jenis mata lainnya, antara lain:

1) emas lebih tahan lama dibandingkan komoditas lain termasuk dengan sejumlah jenis logam sendiri. Emas tidak dapat beroksidasi dengan mudah sehingga ia anti karat. Ia tetap stabil dan tahan dalam jangka waktu yang sangat panjang. Meski emas tenggelam ke dalam lautan bergaram misalnya namun ia tetap dalam bentuk aslinya dan tidak mengalami perubahan. ${ }^{23}$ Emas yang telah diproduksi ratusan tahun silam nilainya sama dengan emas yang baru saja diproduksi. Tak heran jika emas merupakan sarana penyimpan kekayaan (store of value) yang paling baik. Bandingkan dengan komoditas lain seperti kertas meski dapat digunakan sebagai media tukar (medium of exchange) namun ia tidak dapat menyimpan kekayaan dalam waktu lama. ${ }^{24}$

2) emas merupakan logam yang dapat dibagi-bagi (diversiblity) dalam ukuran kecil dan dapat dilebur kembali seperti semula. Dengan sifat tersebut ia dapat menjadi alat tukar yang dapat diubah menjadi sesuatu yang berguna kapan saja dengan tetap menjaga nilainya. Ia bisa menjadi perhiasan atau perkakas pada suatu hari dan dijadikan uang hari berikutnya.

3) emas merupakan komoditas yang bernilai tinggi (luxury good). Komoditas tersebut memiliki nilai unit yang tinggi meski ukurannya kecil. Oleh karena itu seseorang hanya membutuhkan sedikit emas untuk

${ }^{22}$ Ibid, h. 180

${ }^{23}$ Ahamed Kameel Mydin Meera, The theft of Nations Returning to Gold, (Malaysia; Pelanduk Publications, 2004), 72

${ }^{24}$ Jack Weatherford, Sejarah Uang, (Yogyakarta; Bentang Pustaka, 2005), 16 
melakukan transaksi barang dan jasa dalam ukuran besar. Nilai satu ounce emas misalnya setara dengan setengah ton lempeng besi. ${ }^{25}$ Emas juga berbeda dengan mata uang kertas yang nilainya ditentukan oleh kekuatan hukum suatu negara dimana nilai intrinsiknya jauh di bawah nilai nominalnya. Nilai emas ditopang oleh fisiknya sendiri.

4) emas termasuk komoditas yang dapat diterima secara luas (universally) oleh masyarakat dunia sebagai benda bernilai sekaligus dapat dijadikan sebagai alat tukar. Bandingkan misalnya dengan dolar AS, meski telah menjadi mata uang internasional, namun tetap saja ia kalah pamor dengan emas. Tidak semua orang di dunia ini mau menerima dolar sebagai alat transaksi apalagi ketika perekonomian AS mengalami ketidastabilan.

5) emas bersifat langka. Ia tidak dapat diperoleh dengan mudah. Hal ini berbeda dengan uang kertas yang dengan mudah dapat diciptakan melalui mesin cetak. Apalagi dengan kecanggihan tehnologi percetakan yang terus berkembang membuat uang kertas begitu mudah untuk ditiru. ${ }^{26}$

Dengan keunggulan fisik tersebut tidak heran jika emas dalam kurun waktu yang cukup lama baik di masa primitif maupun di masa modern telah dijadikan sebagai mata uang yang paling tangguh baik sebagai alat tukar (medium of transaction) maupun sebagai penyimpan kekayaan (store of value).

\section{Kesimpulan}

Berdasarkan pemaparan diatas, dapat diambil kesimpulan bahwa dinar dan dirham mampu dan bisa menjadi solusi dari sistem moneter internasional dan menggantikan sistem moneter yang berlaku saat ini. Maka merupakan suatu yang ideal bagi semua negara-negara muslim guna memulai langkah untuk menerapkan sistem moneter yang Islami tersebut yaitu dinar dan dirham.

\section{Daftar Pustaka}

Alia. 2004. "Dinar Aman, Menguntungkan, Bebas Riba". Jakarta: Alia.

al-Kattani, Abdul Hay. (t.t.). The Sistem Of Propethic Development Goverment Calld The Administrative Procedure. Vol. II. Beirut: Dar Ihya At-thuras al 'Arabi.

An-Nabhany, Taqiyuddin. 1999. An Nidzamu al-Iqtishady fi Islam. Jakarta: Dârul Ummah.

Grenspan, Alan, Gold and Economic Freedom. 1966. http://www.goldeagle.com/greenspan041998.html

\footnotetext{
25 Alan Grenspan, "Gold and Economic Freedom”, <http://www.goldeagle.com/greenspan041998.html>

${ }^{26}$ Ibid, Ahamed Kameel, 72
} 
Hamidi, M. Luthfi. 2007. Gold Dinar; Sistem Moneter yang Stabil dan Berkeadilan. Jakarta; Senayan Abadi Publishing.

Iqbal, Muhaimin. 2009. Dinar the Real Money. Jakarta: Gema Insani Press.

Karim, Adirwarman. 2002. Ekonomi Islam; Suatu Kajian Kontemporer. Jakarta: Gema Insani Press.

Mirakhor, Abbas. \& al-Hasani, Baghir. 1989. Essay on Iqtisâd Islamic Approach to Economic Problems. USA: Nur.

Mydin Meera, Ahamed Kameel. 2004. The Theft of Nations Returning to Gold, Malaysia; Pelanduk Publications.

Perwataatmadja, Karnaen. \& Syafi'i Antonio, Muhammad. 1992. Apa Dan Bagaimana Bank Islam. Jogjakarta: Dana Bakti Wakaf. 